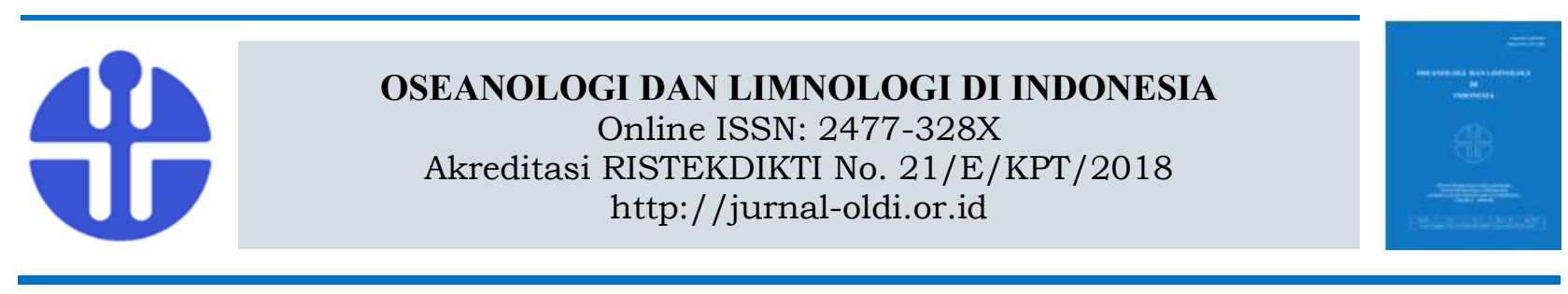

\title{
Komunitas Ikan Karang di Pulau Ternate dan Sekitarnya
}

\section{Rizkie Satriya Utama ${ }^{1}$, Isa Nagib Edrus ${ }^{2}$ dan Petrus Christianus Makatipu ${ }^{3}$}

${ }^{1}$ Pusat Penelitian Oseanografi - LIPI, Jl. Pasir Putih I Ancol Timur, Jakarta 14430; ${ }^{2}$ Balai Penelitian Perikanan Laut, KKP, Cibinong, Bogor; ${ }^{3}$ Loka Konservasi Biota Laut LIPI, Bitung

Email: rizkie.s.u.biogama@gmail.com

Submitted 26 November 2018. Reviewed 31 January 2019. Accepted 10 April 2019.

DOI: 10.14203/oldi.2019.v4i1.228

\begin{abstract}
Abstrak
Pengembangan wilayah pesisir di Maluku Utara menempatkan terumbu karang beserta sumber daya ikan karang menjadi aset penting bagi daerah yang sekaligus rentan terhadap pengaruh pembangunan. Penelitian yang dilakukan pada tahun 2015 hingga 2017, bertujuan untuk melihat perkembangan komunitas ikan karang. Metode yang digunakan adalah sensus visual pada transek sabuk permanen dengan indikator "monitoring" delapan famili ikan karang. Hasil penelitian kategori fungsional ikan menunjukkan bahwa terdapat 108 spesies ikan karang yang terdiri dari 31 spesies ikan indikator koralivora, 45 spesies ikan herbivora, dan 32 spesies karnivora. Rata-rata kepadatan kelompok koralivora mencapai $1.598 \pm 283$ ekor/ha, herbivora $4.751 \pm 1.034 \mathrm{ekor} / \mathrm{ha}$ dan karnivora $890 \pm 622 \mathrm{ekor} / \mathrm{ha}$. Rata-rata sediaan ikan mencapai $420 \pm 162$ $\mathrm{kg} / \mathrm{ha}$ yang terbagi atas kelompok ikan herbivora $320 \pm 130 \mathrm{~kg} / \mathrm{ha}$ dan kelompok ikan karnivora $100 \pm 64$ $\mathrm{kg} / \mathrm{ha}$. Kelompok ikan indikator yang dominan diantaranya Chaetodon baronessa, C. kleinii, C. lunulatus, C. melannotus, C. octofasciatus, C. trifascialis, dan Heniochus varius. Kehadiran ikan karang di pesisir Maluku Utara didominasi oleh ikan herbivora dengan perbandingan $84 \%$ dan 16\% dengan ikan karnivora. Ikan herbivora yang dominan antara lain Acanthurus pyroferus, Chlorurus bleekeri, C. sordidus, Ctenochaetus binotatus, C. striatus, Scarus dimidiatus, S. ghobban, Siganus vulpinus, dan Zebrasoma scopas. Kelompok karnivora yang menonjol hanya Lutjanus biguttatus. Jumlah spesies dan kepadatan pada sebagian besar stasiun penelitian ikan-ikan kelompok koralivora, herbivora dan karnivora mengalami peningkatan sejak 2015 hingga 2017. Sebaliknya pada waktu yang sama, biomassa ikan kelompok herbivora dan karnivora tidak mengalami kenaikan pada sebagian besar lokasi penelitian.
\end{abstract}

Kata kunci: Ikan karang, struktur komunitas, Ternate, Maluku Utara

\section{Abstracts}

Reef Fish Community in the Adjacent Waters of Ternate Island. Considering that the development of coastal region in the North of Moluccas may affect the population of reef fishes, a research on coral reef community structure is performed using underwater visual cencus on a permanent belt transect. The selected indicator monitoring used were eight families of reef fishes. A total of 108 species of reef fishes were identified, consisted of 31 species of corallivorous, 45 species of herbivorous fishes and 32 species carnivorous fishes (based on punctuation group). Density means of a corallivorous group is $1.598 \pm 283$ individual/ha, a herbivorous group is $4.751 \pm 1.034$ individual/ha, and a carnivorous group is $890 \pm 622 \mathrm{ekor} / \mathrm{ha}$. The average of reef fish stocks is $420 \pm 162 \mathrm{~kg} / \mathrm{ha}$ that consist of $320 \pm 130 \mathrm{~kg} / \mathrm{ha}$ for herbivorous fishes and $100 \pm 64 \mathrm{~kg} / \mathrm{ha}$ for carnivorous fishes. Indicator fish dominance were attained by Chaetodon baronessa, C. kleinii, C. lunulatus, C. melannotus, C. octofasciatus, C. trifascialis, and Heniochus varius. Herbivorous fishes (84\%) more dominat than carnivorous (16\%) in terms of individual composition. Dominant species of herbivorous 
fishes included Acanthurus pyroferus, Chlorurus bleekeri, C. Sordidus, Ctenochaetus binotatus, C. striatus, Scarus dimidiatus, S. ghobban, Siganus vulpinus, and Zebrasoma scopas. The one of carnivorous fishes dominated was only Lutjanus biguttatus. Increasing trend of species numbers and density for corallivorous, herbivorous and carnivorous fishes occured from 2015 until 2017 in majority of study sites. In contrast, the biomass values not increased in majority of the sampling sites.

Keyword: Reef fishes, community struktures, Ternate, North Molluccas

\section{Pendahuluan}

Terumbu karang sebagai habitat ikan karang telah mengalami degradasi secara global selama beberapa dekade (Hoegh-Guldberg 2011). Ikan karang memiliki kemampuan merespon yang cukup cepat terhadap adanya perubahan. Struktur komunitas, seperti misalnya keanekaragaman ikan karang, adalah petunjuk yang terukur untuk mengetahui perubahan lingkungan hidup. Perubahan dalam ekosistem terumbu karang sebagai akibat pengaruh eksternal dari luar terumbu, seperti adanya sedimentasi, secara signifikan dapat mempengaruhi struktur komunitas ikan karang, terutama keragaman, komposisi, dan kepadatan ikan karang (Amesbury 1981; Edrus dan Setyawan 2013). Pengaruh eksternal yang dipertimbangkan dapat menjadi ancaman meluas pada terumbu karang juga berasal dari sektor perikanan, seperti bom (blash fishing), dan racun (cyanide fishing) (Slade dan Kalangahe 2015) dan Michael (2011). Apabila perusakan lingkungan yang disebabkan racun cyanida seperti ini tidak dapat dicegah, diperkirakan tahun 2020 semua terumbu karang akan rusak (Michael 2011).

Indonesia memiliki 113 famili ikan yang berasosiasi dengan terumbu karang (Allen dan Adrim 2003). Dartnall dan Jones (1986) membagi kelompok ikan karang berdasarkan fungsi pemanfaatan dan aspek ekologi, yaitu kelompok ikan target, kelompok ikan mayor, dan kelompok ikan indikator. Ikan target merupakan ikan komoditas ekonomis penting sebagai tangkapan nelayan untuk ikan konsumsi. Ikan major adalah ikan yang sebagian besar sebagai penetap dalam terumbu karang dan berukuran relatif kecil, dan sering menjadi target tangkapan sebagai ikan hias atau justru menjadi mangsa ikan predator. Chaetodontidae merupakan ikan indikator pemakan polip karang (koralivora) yang dapat dikaitkan dengan prediksi kesehatan terumbu karang (Shidqi et al. 2018). Kecuali itu, pengelompokan ikan karang juga sering ditentukan menurut status fungsional dalam kebiasaan makan, seperti karnivora, herbivora, omnivora, atau planktivora (Green dan Bellwood 2009). Jika komposisi karnivora mendominasi, sebagai puncak tertinggi dari rantai makanan (top predator), sering dianggap dapat membatasi kelompok fungsional lain (Halford et al. 2004). Sementara kelompok herbivora berperan penting sebagai pengendali pertumbuhan alga dan mampu memberikan daya lenting (resiliensi) pada proses pemulihan karang dalam pengertian menyediakan substrat untuk penempelan planula karang baru (reef rekruitmen). Dengan demikian keseimbangan antara kelompok fungsional tersebut menjadi informasi penting ditengah tekanan pemanfaatan ikan karang meningkat (Obura dan Grimsditch 2009).

Dalam pandangan pengelolaan sumberdaya ikan karang, pengelompokan ikan tersebut menjadi berarti ketika dihadapkan pada pemanfaatan ikan karang selama ini, atas asumsi bahwa sektor perikanan dapat mengubah struktur komunitas ikan karang (Wilson et al. 2006). Upaya monitoring atas indikator tertentu pada perubahan yang dimaksud adalah hanya mengambil sebagian kecil famili ikan karang yang dapat mewakili kelompok ikan target dari karnivora dan herbivora serta kelompok ikan indikator dari kelompok koralivora (Giyanto et al. 2014). Penelitian ini bertujuan untuk menganalisis struktur komunitas ikan karang, terutama keragaman spesies ikan, kelimpahan, komposisi, dan biomassa agar dapat digunakan dalam keperluan pengelolaan terumbu karang.

\section{Metodologi}

Lokasi monitoring meliputi area terumbu karang di perairan sekitar Pulau Ternate, Tidore, dan Halmahera bagian Barat. Titik lokasi pengambilan data dapat dilihat pada Gambar 1 dan titik kordinat pada Tabel 1. Pengambilan data dilakukan pada bulan Agustus 2017, sedangkan data tahun 2015 (Petrus et al. 2015) dan 2016 (Suyarso et al. 2016) digunakan sebagai data pembanding.

Metode Underwater Visual Census (UVC) digunakan untuk pengumpulan data spesies ikan, jumlah individu ikan (Giyanto et al. 2014), dan ukuran panjang ikan (Wilson dan Green 2009). Target pencatatan ikan karang dilakukan meliputi kelompok ikan indikator (famili Chaetodontidae) dan tujuh famili (memiliki nilai ekonomis yang 
tinggi dan banyak dikonsumsi) yaitu Scaridae, Acanthuridae, Siganidae, Haemulidae, Lethrinidae, Lutjanidae, dan Serranidae. Pengelompokkan ikan berdasarkan kelompok fungsionalnya mengacu pada data di Fish Base (Froese dan Pauly 2018) dan identifikasi spesies ikan karang mengacu pada Allen dan Erdmann (2012) dan Allen et al. (2009). Untuk menggambarkan komunitas ikan karang di daerah monitoring dilakukan beberapa analisis sebagai berikut:

1. Keanekaragaman spesies, yaitu jumlah total dari spesies ikan karang yang diamati selama monitoring di suatu lokasi ekosistem terumbu karang.

2. Densitas (D), adalah jumlah individu seluruh spesies ikan karang per luas area pengamatan.

$=\frac{\sum \text { individu(ikan indikator, ikan target: setiap famili) }}{350 \mathrm{~m}^{2}}$
$=X$ individu $/ \mathrm{m}^{2}$

3. Hubungan panjang-berat, adalah berat individu ikan target $(W)$ sama dengan indeks spesifik spesies (a) dikalikan dengan estimasi panjang total dipangkat indeks spesifik spesies $(b)$. Indeks spesifik spesies $(a, b)$ dan panjang ikan disubstitusikan ke rumus panjang berat $W$ $=a \times L^{b}$ untuk mendapatkan data berat ikan (gram/kg). Nilai "a" dan "b" dapat dicari di situs web "fishbase" untuk setiap spesies ikan target Froese dan Pauly (2014).

4. Sediaan ikan per luasan sensus

Sediaan ikan dalam satuan biomassa $(B)$ adalah berat individu ikan target $(W)$ per luas area pengamatan.

$$
B=\frac{W(\text { total setiap famili) }}{350 \mathrm{~m}^{2}}
$$

5. Data jumlah spesies dan kelimpahan individu ikan karang yang diambil secara berkala setiap tahunnya dibandingkan dengan data awal (tahun basis 2015) dan tahun-tahun setelah tahun basis (2016 dan 2017).

Monitoring ini yang bertujuan untuk melihat perubahan (dampak) pada komunitas ikan karang, analisis "before and after" digunakan untuk membandingkan parameter keanekaragaman, jumlah spesies, kepadatan, komposisi dan biomassa dari delapan famili yang ditetapkan antara 2015 sebagai tahun basis dan 2016 sebagai tahun antara dan 2017 sebagai tahun terakhir.

Tabel 1. Posisi geografis lokasi stasiun penelitian dan wilayah administrasinya.

Table 1. Geographyical positions of the study sites and its administrative regions.

\begin{tabular}{lccll}
\hline \multicolumn{1}{c}{ Locations } & $\begin{array}{c}\text { Stations } \\
\text { Codes }\end{array}$ & \multicolumn{2}{c}{ Coordinantes } & Remarks \\
\hline \multirow{4}{*}{ Ternate Island } & TTEC01 & $127.32267^{\circ}$ & $0.88144^{\circ}$ & Hiri Island \\
Waters & TTEC02 & $127.33157^{\circ}$ & $0.86494^{\circ}$ & Nothern Ternate Island \\
& TTEC03 & $127.38635^{\circ}$ & $0.83451^{\circ}$ & Easthern Ternate Island \\
& TTEC04 & $127.39087^{\circ}$ & $0.78717^{\circ}$ & Easthern Ternate Island \\
& TTEC05 & $127.32404^{\circ}$ & $0.75325^{\circ}$ & SouthernTernate Island \\
\hline \multirow{4}{*}{ Tidore Island } & TTEC06 & $127.36523^{\circ}$ & $0.74245^{\circ}$ & Northern Maitara Island \\
Waters & TTEC07 & $127.37496^{\circ}$ & $0.72276^{\circ}$ & Southern Maitara Island \\
& TTEC08 & $127.43081^{\circ}$ & $0.75204^{\circ}$ & Northern Tidore Island \\
& TTEL09 & $127.45589^{\circ}$ & $0.73095^{\circ}$ & Easthern Tidore Island \\
& TTEC10 & $127.47985^{\circ}$ & $0.71444^{\circ}$ & Easthern Tidore Island \\
& TTEC11 & $127.45757^{\circ}$ & $0.69584^{\circ}$ & Easthern Tidore Island \\
Halmahera Island & TTEC12 & $127.49722^{\circ}$ & $0.86831^{\circ}$ & Halmahera Island (Sidangoli \\
Waters & TTEC13 & $127.61461^{\circ}$ & $0.85239^{\circ}$ & Hallage Areas) \\
& & & & Village Areas) \\
& TTEC14 & $127.59373^{\circ}$ & $0.77259^{\circ}$ & Halmahera Island (Sofifi \\
& & & & Village Areas) \\
\hline
\end{tabular}




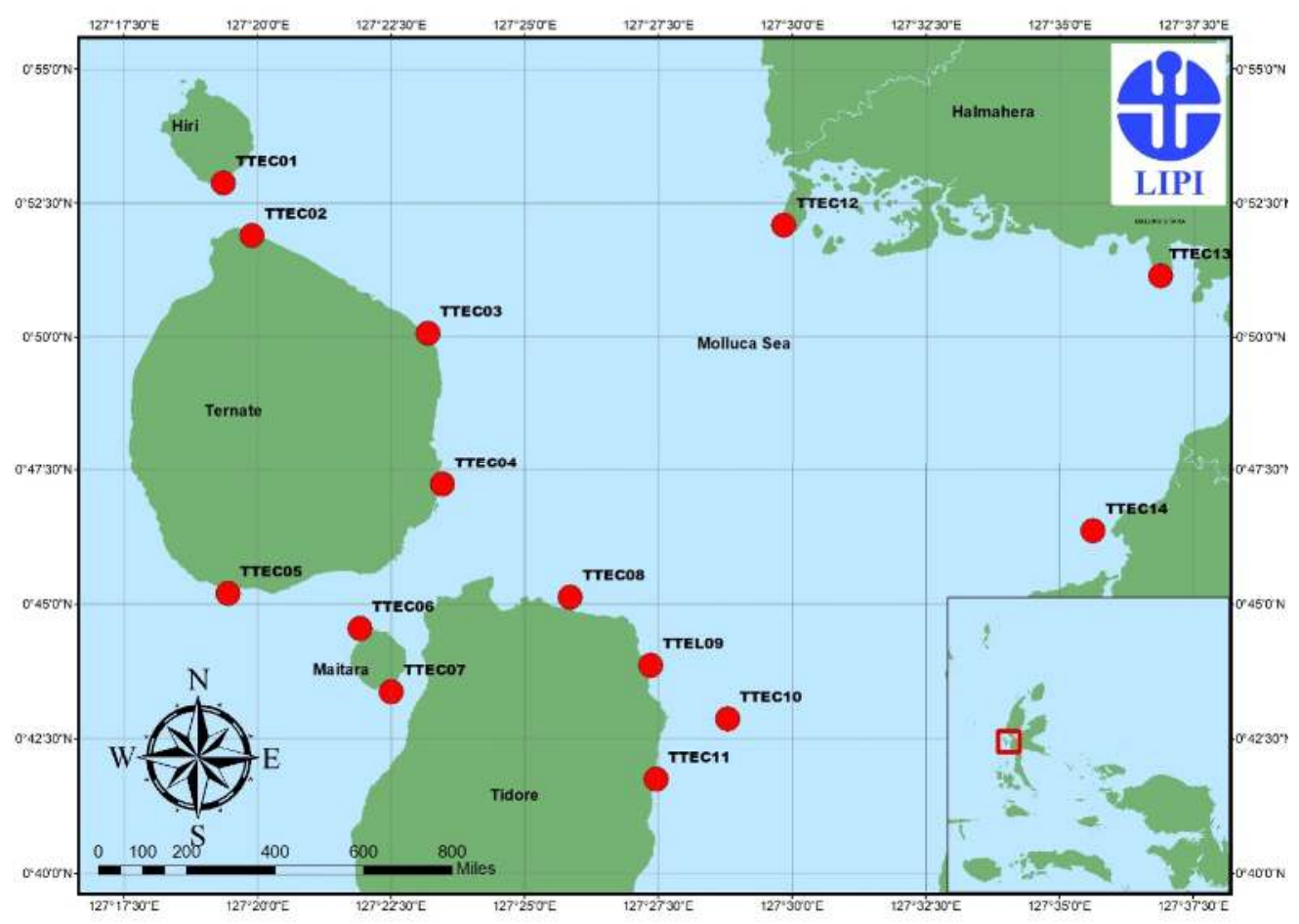

Gambar 1. Lokasi transek pada stasiun penelitian.

Figure 1. Transect locations in the study sites.

\section{Hasil}

\section{Jumlah Spesies}

Hasil sensus visual pada 14 stasiun penelitian menemukan total 31 spesies indikator dari famili Chaetodontidae dan 77 spesies ikan target dari tujuh famili terpilih yang menurut status fungsional ikan, jumlah tersebut terdiri dari 31 spesies obligate karang (koralivora), 45 spesies herbivora, dan 32 spesies karnivora.

Rata-rata jumlah spesies koralivora 12,6 \pm 2,8 spesies/stasiun, rata-rata jumlah spesies dari total tujuh famili terpilih $29 \pm 6$ spesies/stasiun, dimana rata-rata jumlah spesies kelompok herbivora saja adalah $19 \pm 4,3$ spesies/stasiun dan kelompok karnivora saja $9 \pm 3,3$ spesies/stasiun. Jumlah spesies terendah ikan indikator adalah tujuh spesies pada stasiun TTEC 13 dan tertinggi 19 spesies pada stasiun TTEC 02. Jumlah spesies terendah ikan karang dari 7 famili terpilih adalah 18 spesies pada stasiun TTEC 08 dan tertinggi 41 spesies pada stasiun TTEC 04 (Tabel 2). Tabel ini menunjukkan bahwa jumlah spesies kelompok ikan herbivora lebih tinggi dari kelompok ikan koralivora dan karnivora.

\section{Kepadatan}

Rata-rata jumlah individu kelompok ikan koralivora (Chaetodontidae) dari 14 stasiun penelitian adalah $56 \pm 10$ ekor/ $350 \mathrm{~m}^{2}$ atau setara dengan $1.598 \pm 283$ ekor/ha. Sebaran jumlah ikan ini tidak merata pada setiap stasiun dengan simpangan baku cukup besar. Stasiun-stasiun yang memiliki dominasi ikan indikator tertinggi adalah TTEC 02, TTEC 03, TTEC 07, TTEC 09, dan TTEC 14. Stasiun TTEC 13 merupakan stasiun dengan jumlah ikan indikator paling rendah (Tabel 2).

Rata-rata jumlah individu ikan karang dari tujuh famili terpilih $197 \pm 40$ ekor/350 $\mathrm{m}^{2}$ atau setara dengan $5.641 \pm 1155$ ekor/ha. Kepadatan ini terbagi atas rata-rata kepadatan kelompok famili herbivora $166 \pm 36$ ekor $/ 350 \mathrm{~m}^{2}$ yang setara dengan $4.751 \pm 1.034$ dan rata-rata kepadatan kelompok famili karnivora $31 \pm 22$ ekor $/ 350 \mathrm{~m}^{2}$ yang setara dengan $890 \pm 622$ ekor/ha.

Stasiun penelitian yang memiliki kepadatan ikan karang tertinggi adalah TTEC 09 (293 ekor/m2 atau $8.371 \mathrm{ekor} / \mathrm{ha}$ ), didominasi oleh kelompok herbivora (96\%), sedangkan stasiun TTEC 04 juga memiliki kepadatan tinggi dengan rasio antara herbivora dan karnivora $62 \%: 38 \%$. Stasiun dengan kepadatan paling rendah adalah TTEC 08, didominasi oleh ikan herbivora (96\%). Variasi kepadatan pada setiap stasiun disajikan pada Tabel 2. 
Tabel 2. Struktur komunitas ikan karang di perairan karang Ternate dan sekitarnya, 2017.

Table 2. Reef-fish community structures in around of Ternate reef waters, 2017.

\begin{tabular}{|c|c|c|c|c|c|c|c|c|c|c|c|c|c|c|}
\hline \multirow[b]{2}{*}{ Category } & \multicolumn{14}{|c|}{ Station Codes } \\
\hline & $\begin{array}{l}\overrightarrow{7} \\
\stackrel{7}{7}\end{array}$ & 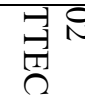 & 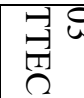 & 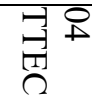 & 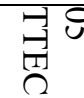 & 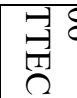 & $\begin{array}{l}\overrightarrow{7} \\
\text { 藏 }\end{array}$ & 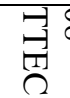 & $\begin{array}{l}\mathrm{H} \\
\mathrm{H} \\
\mathrm{T}\end{array}$ & $\begin{array}{l}\text { 국 } \\
\stackrel{7}{\Omega}\end{array}$ & 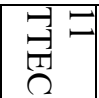 & 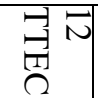 & 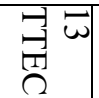 & $\begin{array}{l}\mathrm{H} \\
\stackrel{7}{\mathrm{~T}} \\
\mathrm{~S}\end{array}$ \\
\hline \multicolumn{15}{|c|}{ Spesies number } \\
\hline Corallivore & 16 & 19 & 15 & 15 & 14 & 13 & 16 & 9 & 10 & II & 10 & II & 7 & II \\
\hline Herbivore & 24 & 20 & 26 & 24 & 14 & 18 & 13 & 14 & 23 & 15 & 25 & 13 & 22 & 17 \\
\hline Carnivore & II & 3 & 9 & 17 & 14 & 15 & II & 4 & 8 & II & 8 & 7 & 10 & 4 \\
\hline TOTAL & 51 & 42 & 50 & 56 & 42 & 46 & 40 & 27 & 41 & 37 & 43 & 31 & 39 & 32 \\
\hline \multicolumn{15}{|c|}{ Individual Number (Individu/350m2) } \\
\hline Corallivore & 5 & 69 & 69 & 47 & 49 & 58 & 66 & 54 & 78 & 46 & 52 & 45 & 34 & 65 \\
\hline Herbivore & 171 & 142 & 185 & 157 & 108 & 165 & 225 & 100 & 280 & 196 & 194 & I06 & 150 & 149 \\
\hline Carnivore & 18 & 5 & 14 & 95 & 30 & 30 & 17 & 4 & 13 & 66 & 22 & 65 & 51 & 5 \\
\hline TOTAL & 240 & 216 & 268 & 299 & 187 & 253 & 308 & 158 & 371 & 308 & 268 & 216 & 235 & 220 \\
\hline \multicolumn{15}{|c|}{ Density ((Individu / ha) } \\
\hline Corallivore & 1457 & 1971 & 1971 & 1343 & 1400 & 1657 & 1886 & 1543 & 2229 & 1314 & 1486 & 1286 & 971 & 1857 \\
\hline Herbivore & 4.886 & 4.057 & 5.286 & 4.486 & 3.086 & 4.714 & 6.429 & 2.857 & 8 & 5.6 & 5.543 & 3.029 & 4.286 & 4.257 \\
\hline Carnivore & 514 & 143 & 400 & 2.714 & 857 & 857 & 486 & 114 & 371 & 1.886 & 629 & 1.857 & 1.457 & 171 \\
\hline TOTAL & 6857 & 6171 & 7657 & 8543 & 5343 & 7229 & 8800 & 4514 & 10600 & 8800 & 7657 & 6171 & 6714 & 6286 \\
\hline \multicolumn{15}{|c|}{ BIOMASS (Gr/350m2) } \\
\hline Herbivore & 13314 & 11354 & 13452 & 14298 & 4957 & 12558 & 8694 & 4287 & 30618 & 11256 & 14528 & 4314 & 7093 & 6028 \\
\hline Carnivore & 2578 & 347 & 1624 & 10603 & 3555 & 4211 & 1635 & 207 & 3158 & 8157 & 2266 & 3230 & 6739 & 624 \\
\hline TOTAL & 15891 & 11701 & 15075 & 24901 & 8512 & 16769 & 10329 & 4494 & 33776 & 19413 & 16794 & 7543 & 13832 & 6652 \\
\hline \multicolumn{15}{|c|}{ STOCKS (Kg / ha) } \\
\hline Herbivore & 380 & 324 & 384 & 409 & 142 & 359 & 248 & 122 & 875 & 322 & 415 & 123 & 203 & 172 \\
\hline Carnivore & 74 & 10 & 46 & 303 & 102 & 120 & 47 & 6 & 90 & 233 & 65 & 92 & 193 & 18 \\
\hline TOTAL & 454 & 334 & 431 & $7 \|$ & 243 & 479 & 295 & 128 & 965 & 555 & 480 & 216 & 395 & 190 \\
\hline
\end{tabular}

\section{Biomassa}

Variasi biomasa ikan terumbu karang dari tujuh famili terpilih antar stasiun penelitian cukup besar, ditunjukkan oleh nilai simpangan baku yang tinggi. Rata-rata sediaan ikan $14,7 \pm 5,7 \mathrm{~kg} / 350 \mathrm{~m}^{2}$ atau setara dengan $420 \pm 162 \mathrm{~kg} / \mathrm{ha}$, dimana ratarata untuk kelompok ikan herbivora 11,2 $\pm 4,5$ $\mathrm{kg} / 350 \mathrm{~m} 2$ atau setara dengan $320 \pm 130 \mathrm{~kg} / \mathrm{ha}$ dan untuk kelompok ikan karnivora 3,5 $\pm 2,2 \mathrm{~kg} / 350 \mathrm{~m}^{2}$ atau setara dengan $100 \pm 64 \mathrm{~kg} / \mathrm{ha}$. Stasiun yang memiliki sediaan ikan tertinggi adalah TTEC 09, yaitu sebesar $965 \mathrm{~kg} / \mathrm{ha}$ dengan dominasi kelompok ikan herboivora 91\% untuk stasiun tersebut. Stasiun yang memiliki sediaan ikan terendah adalah TTEC 08 dengan nilai $128 \mathrm{~kg} / \mathrm{ha}$ dan dominasi kelompok ikan herboivora 95\%. Tabel 2 menunjukkan variasi sediaan pada masingmasing stasiun penelitian.

\section{Komposisi}

Kelompok ikan indikator yang memiliki sebaran luas dan jumlah individunya terbanyak sebagai 10 besar (Gambar 2) meliputi Chaetodon kleinii (16,3\%), Chaetodon lunulatus (12,6\%), Chaetodon baronessa $(9,1 \%)$, Heniochus varius (8\%), Chaetodon melannotus (7\%), Chaetodon trifascialis (6,3\%), Chaetodon octofasciatus (5,7\%), Chaetodon vagabundus (4,7\%), Heniochus chrysostomus $(4,1 \%)$, dan Chaetodon ocellicaudus $(3,7 \%)$.

Spesies ikan terumbu karang dari tujuh famili terpilih yang termasuk 10 besar dalam jumlah individunya meliputi Ctenochaetus striatus, Ctenochaetus binotatus, Zebrasoma scopas, Scarus ghobban, Lutjanus biguttatus, Acanthurus pyroferus, Chlorurus sordidus, Chlorurus bleekeri, Siganus vulpinus, dan Scarus dimidiatus. Dari 10 spesies tersebut, terdapat 9 spesies herbivora dari kelompok ikan kakatua dan ikan butana dan hanya satu spesies karnivora dari kelompok kakap (Lutjanus biguttatus). Secara rinci komposisi dalam jumlah individu didominasi oleh kelompok ikan herbivora sebesar $84 \%$ dan sisanya karnivora 16\% (Tabel 3). 
Utama et al.

Komposisi dalam biomassa diwakili oleh 10 besar spesies ikan yang meliputi Chlorurus bleekeri, Scarus ghobban, Lutjanus biguttatus, Chlorurus sordidus, Naso lituratus, Naso vlamingii, Naso hexacanthus, Ctenochaetus striatus, Siganus canaliculatus, dan Zebrasoma scopas (Tabel 4). Urutan komposisi biomassa berbeda dari urutan komposisi jumlah individual karena ukuran tubuh ikan menentukan beratnya.
Sebagai contoh spesies Ctenochaetus striatus, Ctenochaetus binotatus, Zebrasoma scopas, Siganus vulpinus, dan Scarus dimidiatus adalah ikan dengan jumlah individu banyak tetapi memiliki ukuran tubuh kecil, dan banyak dijumpai ukuran anakan. Adapun dominasi dalam bentuk biomassa masih menunjukkan kelompok herbivora yang tertinggi $(76 \%)$.

\section{Composition (\%) of the Corallivorous Fish Indicator Group}

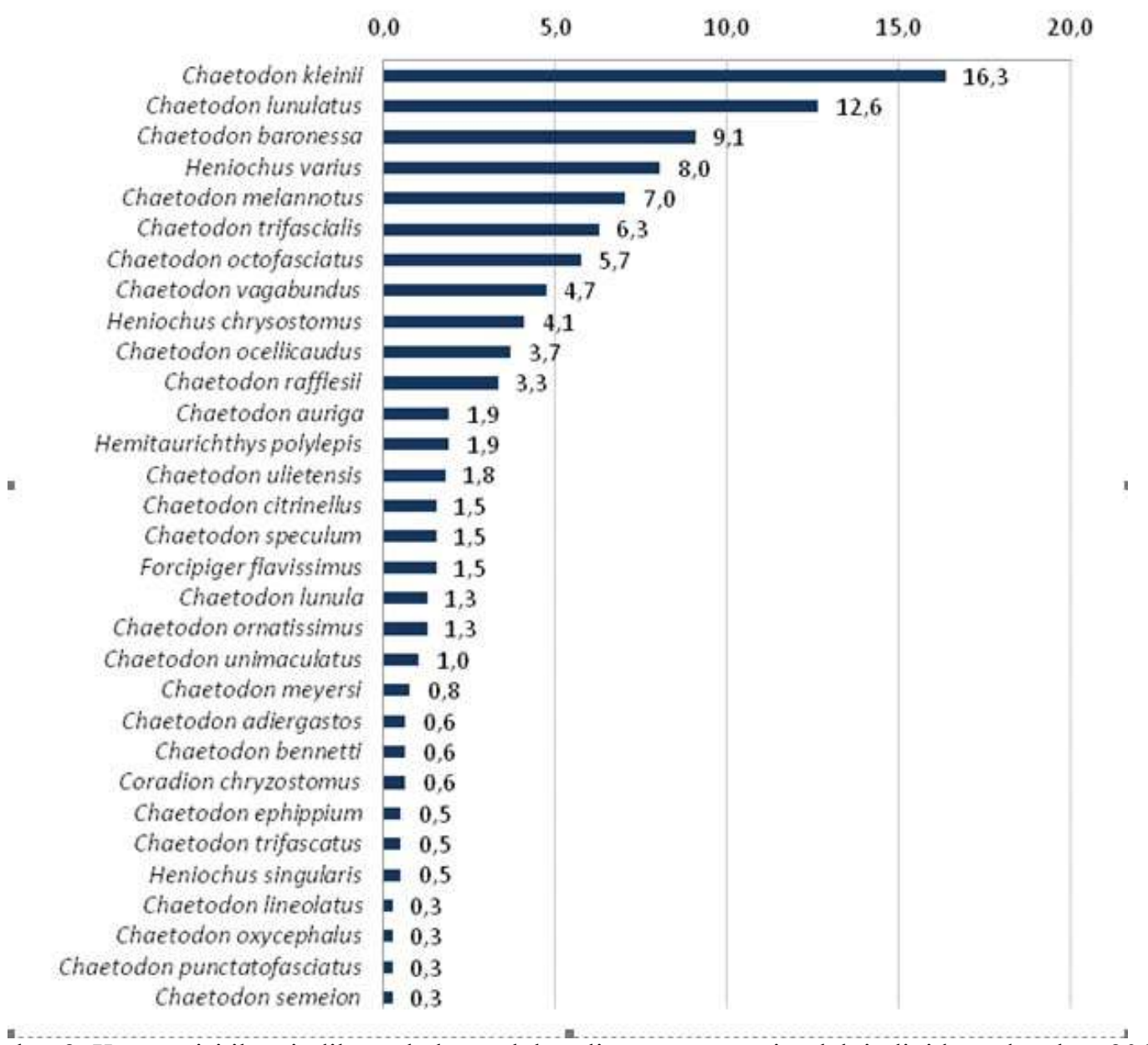

Gambar 2. Komposisi ikan indikator kelompok koralivora menurut jumlah individu pada tahun 2017.

Figure 2. Composition of the corallivorous fish indicator group by individual numbers in 2017.

Dari tujuh famili terpilih untuk ikan karang yang menjadi target penelitian, famili dari kelompok herbivora selalu mendominasi dalam komposisi, baik jumlah individual maupun biomassa. Famili Acanthuridae adalah kelompok herbivora yang tertinggi. Urutan dominasi herbivora berikutnya adalah Scaridae dan Siganidae, sedangkan karnivora yang terbanyak adalah Kakap atau Lutjanidae (Tabel 5).

\section{Perubahan Ikan Indikator}

Total jumlah spesies ikan indikator sebagai kelompok koralivora adalah 27 spesies pada tahun 2015, kemudian pada tahun 2016 dan 2017 teridentifikasi masing-masing 31 spesies. Sebagian besar perkembangan jumlah spesies koralivora menunjukkan adanya spesies tambahan yang tersensus pada tahun 2017 , terutama pada stasiun TTEC 01, 02, 03, 04, 05, 07, 10, dan 14 . Selebihnya pada tahun yang sama terjadi penurunan jumlah spesies pada stasiun TTEC 06, 08, dan 12, 
sedangkan pada stasiun TTEC 11 da 13 tidak terjadi penurunan jumlah spesies (Gambar 3). Rata-rata jumlah spesies dari semua stasiun adalah 10 spesies pada 2015 (Makatipu et al. 2015), dan 11 spesies pada 2016 (Suyarso et al. 2016) serta 12 spesies pada 2017.

Jumlah individu per transek (kepadatan) ikan indikator atau koralivora sebagian besar meningkat di beberapa stasiun penelitian, terutama pada stasiun TTEC 01, 02, 03, 04, 0,5, 07, 10, dan 14. Sebaliknya terjadi penurunan kepadatan pada stasiun TTEC 06, 08, dan 09 serta tidak mengalami perubahan selama dua tahun terakhir pada stasiun TTEC 11 (Gambar 4).

Sepuluh besar spesies ikan indikator dari tahun 2015 sampai 2017 sedikit mengalami perubahan dalam komposisi individualnya (Tabel 6). Pada dominasi tiga besar oleh Chaetodon kleinii, C. Lunulatus, dan Heniochus varius, dua yang pertama tetap menempati dominasi teratas dan Heniochus varius menurun jumlahnya di bawah Chaetodon baronessa yang ukuran populasinya menanjak naik. Selanjutnya urutan di bawah tiga besar, Chaetodon melannotus, $C$. Trifascialis, dan $C$. vagabundus menurun jumlahnya. Chaetodon triangulum dan $C$. trifasciatus yang sempat terdata dan masuk 10 besar pada 2015 dan 2016 menghilang pada 2017. Spesies $C$. raflesi yang sempat termasuk 10 besar pada 2015 dan 2016 mengalami penurunan jumlah individu pada 2017 sehingga masuk pada urutan ke 11, sementara spesies Heniochus chrysostomus yang sempat menurun sampai urutan ke 11 mengalami peningkatan ukuran populasi pada 2017 ke tingkat sembilan besar. Dua spesies yang meningkat dari tahun sebelumnya dan kemudian masuk 10 besar adalah Chaetodon octofasciatus dan C. ocellicaudus.

Tabel 3. Komposisi spesies ikan terumbu karang menurut jumlah individual kelompok herbivora dan karnivora tahun 2017.

Table3. Species composition of reef fishes by individual numbers of herbivorous and carnivorous groups in 2017.

\begin{tabular}{|c|c|c|c|c|c|c|c|}
\hline \multirow{3}{*}{ No. } & \multirow{3}{*}{ SPECIES } & \multicolumn{2}{|c|}{ COMPOSITION } & \multirow{3}{*}{ No. } & \multirow{3}{*}{ SPECIES } & \multicolumn{2}{|c|}{ COMPOSITION } \\
\hline & & Herbivore & Carnivore & & & Herbivore & Carnivore \\
\hline & & $(\%)$ & $(\%)$ & & & $(\%)$ & $(\%)$ \\
\hline 1 & $\begin{array}{l}\text { Ctenochaetus } \\
\text { striatus } \\
\text { Ctenochaetus }\end{array}$ & 12,4 & & 40 & $\begin{array}{l}\text { Chlorurus } \\
\text { capstratoides }\end{array}$ & 0,4 & \\
\hline 2 & $\begin{array}{l}\text { binotatus } \\
\text { Zebrasoma }\end{array}$ & 11,3 & & 41 & $\begin{array}{l}\text { Scarus psittacus } \\
\text { Lethrinus }\end{array}$ & 0,4 & \\
\hline 3 & scopas & 7,4 & & 42 & $\begin{array}{l}\text { erythropterus } \\
\text { Siganus }\end{array}$ & & 0,4 \\
\hline 4 & $\begin{array}{l}\text { Scarus ghobban } \\
\text { Lutjanus }\end{array}$ & 6,2 & & 43 & punctatissimus & 0,4 & \\
\hline 5 & $\begin{array}{l}\text { biguttatus } \\
\text { Acanthurus }\end{array}$ & & 5,8 & 44 & Lethrinus harak & & 0,3 \\
\hline 6 & $\begin{array}{l}\text { pyroferus } \\
\text { Chlorurus }\end{array}$ & 5,8 & & 45 & $\begin{array}{l}\text { Naso unicornis } \\
\text { Cephalopholis }\end{array}$ & 0,3 & \\
\hline 7 & $\begin{array}{l}\text { sordidus } \\
\text { Chlorurus }\end{array}$ & 4,4 & & 46 & $\begin{array}{l}\text { argus } \\
\text { Ctenochaetus }\end{array}$ & & 0,3 \\
\hline 8 & $\begin{array}{l}\text { bleekeri } \\
\text { Siganus }\end{array}$ & 3,9 & & 47 & tominiensis & 0,3 & \\
\hline 9 & $\begin{array}{l}\text { vulpinus } \\
\text { Scarus }\end{array}$ & 3,2 & & 48 & Lutjanus bohar & & 0,2 \\
\hline 10 & dimidiatus & 2,7 & & 49 & $\begin{array}{l}\text { Macolor macularis } \\
\text { Acanthurus }\end{array}$ & & 0,2 \\
\hline 11 & Naso lituratus & 2,4 & & 50 & olivaceus & 0,2 & \\
\hline 12 & $\begin{array}{l}\text { Scarus niger } \\
\text { Siganus }\end{array}$ & 2,3 & & 51 & $\begin{array}{l}\text { Scarus schlegeli } \\
\text { Cephalopholis }\end{array}$ & 0,2 & \\
\hline 13 & $\begin{array}{l}\text { canaliculatus } \\
\text { Naso }\end{array}$ & 2,1 & & 52 & $\begin{array}{l}\text { cyanostigma } \\
\text { Cephalopholis }\end{array}$ & & 0,2 \\
\hline 14 & $\begin{array}{l}\text { hexacanthus } \\
\text { Acanthurus }\end{array}$ & 1,9 & & 53 & $\begin{array}{l}\text { spiloparae } \\
\text { Variola }\end{array}$ & & 0,2 \\
\hline 15 & nigrofuscus & 1,8 & & 54 & albimarginata & & 0,2 \\
\hline
\end{tabular}


Utama et al.

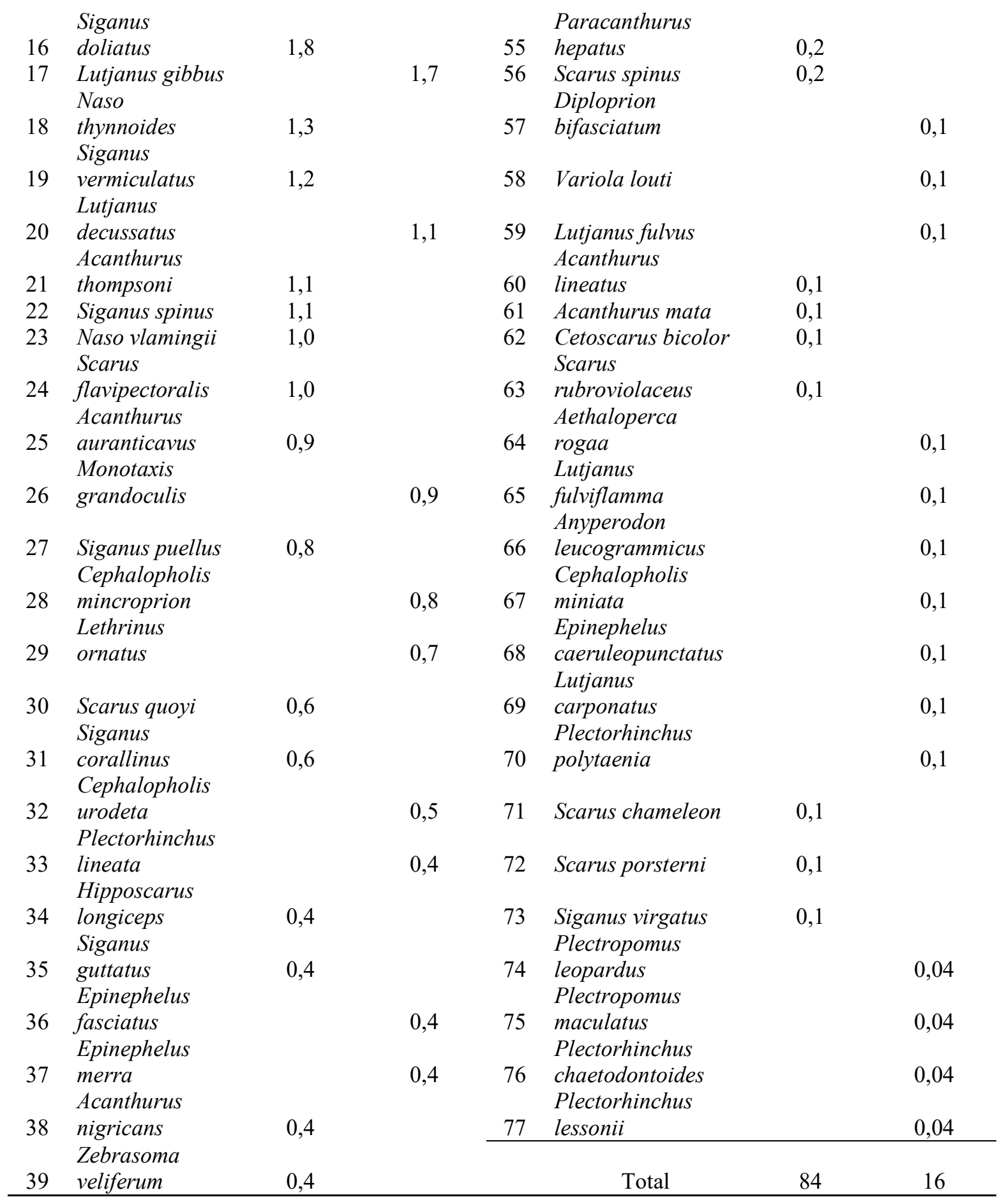


Tabel 4 Komposisi spesies ikan terumbu karang berdasarkan biomassa kelompok herbivora dan karnivora tahun 2017.

Table 4. Species composition of reef fishes by biomass of herbivorous and carnivorous groups in 2017.

\begin{tabular}{|c|c|c|c|c|c|c|c|}
\hline \multirow{3}{*}{ No. } & \multirow{3}{*}{ SPECIS } & \multicolumn{2}{|c|}{ COMPOSITION } & \multirow{3}{*}{ No. } & \multirow{3}{*}{ SPECIES } & \multirow{2}{*}{\multicolumn{2}{|c|}{ COMPOSITION }} \\
\hline & & Herbivore & Carnivore & & & & \\
\hline & & $(\%)$ & $(\%)$ & & & $(\%)$ & $(\%)$ \\
\hline & & & & & Hipposcarus & & \\
\hline 1 & Chlorurus bleekeri & 8,65 & & 40 & longiceps & 0,55 & \\
\hline 2 & $\begin{array}{l}\text { Scarus ghobban } \\
\text { Lutjanus }\end{array}$ & 5,78 & & 41 & Siganus spinus & 0,55 & \\
\hline 3 & $\begin{array}{l}\text { biguttatus } \\
\text { Chlorurus }\end{array}$ & & 5,47 & 42 & Acanthurus mata & 0,54 & \\
\hline 4 & sordidus & 5,17 & & 43 & $\begin{array}{l}\text { Siganus guttatus } \\
\text { Zebrasoma }\end{array}$ & 0,53 & \\
\hline 5 & Naso lituratus & 4,88 & & 44 & veliferum & 0,53 & \\
\hline 6 & Naso vlamingii & 4,44 & & 45 & $\begin{array}{l}\text { Naso unicornis } \\
\text { Lutjanus }\end{array}$ & 0,43 & \\
\hline 7 & $\begin{array}{l}\text { Naso hexacanthus } \\
\text { Ctenochaetus }\end{array}$ & 3,64 & & 46 & $\begin{array}{l}\text { fulviflamma } \\
\text { Plectorhinchus }\end{array}$ & & 0,41 \\
\hline 8 & $\begin{array}{l}\text { striatus } \\
\text { Siganus }\end{array}$ & 3,49 & & 47 & $\begin{array}{l}\text { polytaenia } \\
\text { Cephalopholis }\end{array}$ & & 0,35 \\
\hline 9 & canaliculatus & 3,40 & & 48 & cyanostigma & & 0,33 \\
\hline 10 & $\begin{array}{l}\text { Zebrasoma scopas } \\
\text { Siganus }\end{array}$ & 3,30 & & 49 & Scarus chameleon & 0,31 & \\
\hline 11 & $\begin{array}{l}\text { vermiculatus } \\
\text { Acanthurus }\end{array}$ & 3,29 & & 50 & Scarus dimidiatus & 0,26 & \\
\hline 12 & $\begin{array}{l}\text { auranticavus } \\
\text { Ctenochaetus }\end{array}$ & 3,13 & & 51 & $\begin{array}{l}\text { Variola louti } \\
\text { Cephalopholis }\end{array}$ & & 0,24 \\
\hline 13 & binotatus & 3,12 & & 52 & miniata & & 0,23 \\
\hline 14 & Lutjanus gibbus & & 2,92 & 53 & Cetoscarus bicolor & 0,23 & \\
\hline 15 & $\begin{array}{l}\text { Scarus niger } \\
\text { Monotaxis }\end{array}$ & 2,82 & & 54 & Scarus psittacus & 0,22 & \\
\hline 16 & grandoculis & & 2,49 & 55 & $\begin{array}{l}\text { Lutjanus fulvus } \\
\text { Plectorhinchus }\end{array}$ & & 0,22 \\
\hline 17 & Scarus quoyi & 2,46 & & 56 & $\begin{array}{l}\text { lessonii } \\
\text { Acanthurus }\end{array}$ & & 0,21 \\
\hline 18 & $\begin{array}{l}\text { Naso thynnoides } \\
\text { Plectorhinchus }\end{array}$ & 2,12 & & 57 & thompsoni & 0,21 & \\
\hline 19 & lineata & & 1,62 & 58 & $\begin{array}{l}\text { Aethaloperca rogaa } \\
\text { Diploprion }\end{array}$ & & 0,20 \\
\hline 20 & $\begin{array}{l}\text { Siganus vulpinus } \\
\text { Lutjanus }\end{array}$ & 1,59 & & 59 & bifasciatum & & 0,19 \\
\hline 21 & decussatus & & 1,51 & 60 & Epinephelus merra & & 0,19 \\
\hline 22 & $\begin{array}{l}\text { Siganus doliatus } \\
\text { Acanthurus }\end{array}$ & 1,51 & & 61 & Lutjanus carponatus & & 0,16 \\
\hline 23 & $\begin{array}{l}\text { pyroferus } \\
\text { Macolor }\end{array}$ & 1,46 & & 62 & $\begin{array}{l}\text { Lutjanus bohar } \\
\text { Cephalopholis }\end{array}$ & & 0,15 \\
\hline 24 & $\begin{array}{l}\text { macularis } \\
\text { Chlorurus }\end{array}$ & & 1,37 & 63 & mincroprion & & 0,15 \\
\hline 25 & $\begin{array}{l}\text { capstratoides } \\
\text { Scarus }\end{array}$ & 1,20 & & 64 & $\begin{array}{l}\text { Scarus porsterni } \\
\text { Acanthurus }\end{array}$ & 0,14 & \\
\hline 26 & $\begin{array}{l}\text { flavipectoralis } \\
\text { Lethrinus }\end{array}$ & 1,11 & & 65 & $\begin{array}{l}\text { nigricans } \\
\text { Plectropomus }\end{array}$ & 0,14 & \\
\hline 27 & erythropterus & & 0,90 & 66 & $\begin{array}{l}\text { leopardus } \\
\text { Plectropomus }\end{array}$ & & 0,13 \\
\hline 28 & Siganus corallinus & 0,89 & & 67 & maculatus & & 0,13 \\
\hline
\end{tabular}


Utama et al.

\begin{tabular}{|c|c|c|c|c|c|c|c|}
\hline 29 & Siganus puellus & 0,87 & & 68 & Acanthurus lineatus & 0,12 & \\
\hline 30 & $\begin{array}{l}\text { Lethrinus harak } \\
\text { Scarus }\end{array}$ & & 0,83 & 69 & $\begin{array}{l}\text { Scarus spinus } \\
\text { Cephalopholis }\end{array}$ & 0,11 & \\
\hline 31 & $\begin{array}{l}\text { rubroviolaceus } \\
\text { Siganus }\end{array}$ & 0,76 & & 70 & $\begin{array}{l}\text { spiloparae } \\
\text { Acanthurus }\end{array}$ & & 0,08 \\
\hline 32 & punctatissimus & 0,74 & & 71 & $\begin{array}{l}\text { olivaceus } \\
\text { Paracanthurus }\end{array}$ & 0,07 & \\
\hline 33 & $\begin{array}{l}\text { Lethrinus ornatus } \\
\text { Acanthurus }\end{array}$ & & 0,74 & 72 & $\begin{array}{l}\text { hepatus } \\
\text { Plectorhinchus }\end{array}$ & 0,06 & \\
\hline 34 & nigrofuscus & 0,67 & & 73 & $\begin{array}{l}\text { chaetodontoides } \\
\text { Epinephelus }\end{array}$ & & 0,05 \\
\hline 35 & $\begin{array}{l}\text { Scarus schlegeli } \\
\text { Variola }\end{array}$ & 0,66 & & 74 & $\begin{array}{l}\text { caeruleopunctatus } \\
\text { Anyperodon }\end{array}$ & & 0,05 \\
\hline 36 & $\begin{array}{l}\text { albimarginata } \\
\text { Cephalopholis }\end{array}$ & & 0,64 & 75 & leucogrammicus & & 0,05 \\
\hline 37 & $\begin{array}{l}\text { argus } \\
\text { Epinephelus }\end{array}$ & & 0,61 & 76 & $\begin{array}{l}\text { Siganus virgatus } \\
\text { Ctenochaetus }\end{array}$ & 0,04 & \\
\hline 38 & fasciatus & & 0,60 & 77 & tominiensis & 0,03 & \\
\hline 39 & $\begin{array}{l}\text { Cephalopholis } \\
\text { urodeta }\end{array}$ & & 0,58 & & Total & 76 & 24 \\
\hline
\end{tabular}

Tabel 5. Komposisi famili ikan (\%) berdasarkan jumlah individu dan biomassa tahun 2017.

Table 5. Fish family composition (\%) by individual numbers in 2017.

\begin{tabular}{|c|c|c|c|}
\hline FAMILIES & $\begin{array}{c}\text { COMPOSITION } \\
\text { Individual }\end{array}$ & FAMILIES & $\begin{array}{c}\text { COMPOSITION } \\
\text { Biomassa }\end{array}$ \\
\hline $\begin{array}{l}\text { ACANTHURIDAE } \\
\text { (19 species) }\end{array}$ & 49,5 & $\begin{array}{l}\text { ACANTHURIDAE } \\
\text { (19 species) }\end{array}$ & 32,4 \\
\hline $\begin{array}{l}\text { SCARIDAE (16 } \\
\text { spesies) }\end{array}$ & 23,2 & $\begin{array}{l}\text { SCARIDAE (16 } \\
\text { species) }\end{array}$ & 30,5 \\
\hline $\begin{array}{l}\text { SIGANIDAE (10 } \\
\text { spesies) }\end{array}$ & 11,6 & $\begin{array}{l}\text { SIGANIDAE (10 } \\
\text { species) }\end{array}$ & 13,4 \\
\hline $\begin{array}{l}\text { LUTJANIDAE (8 } \\
\text { spesies) }\end{array}$ & 9,4 & $\begin{array}{l}\text { LUTJANIDAE(8 } \\
\text { species) }\end{array}$ & 12,2 \\
\hline $\begin{array}{l}\text { SERRANIDAE (16 } \\
\text { species) }\end{array}$ & 3,6 & $\begin{array}{l}\text { LETHRINIDAE (4 } \\
\text { species) }\end{array}$ & 5,0 \\
\hline $\begin{array}{l}\text { LETHRINIDAE ( } 4 \\
\text { species) } \\
\text { HAEMULIDAE ( } 4\end{array}$ & 2,2 & $\begin{array}{l}\text { SERRANIDAE (16 } \\
\text { species) } \\
\text { HAEMULIDAE ( } 4\end{array}$ & 4,4 \\
\hline species) & 0,6 & species) & 2,2 \\
\hline
\end{tabular}


Species number Ratios of the indicator fish group identified in 2015, 2016 and

2017 at the same transect areas

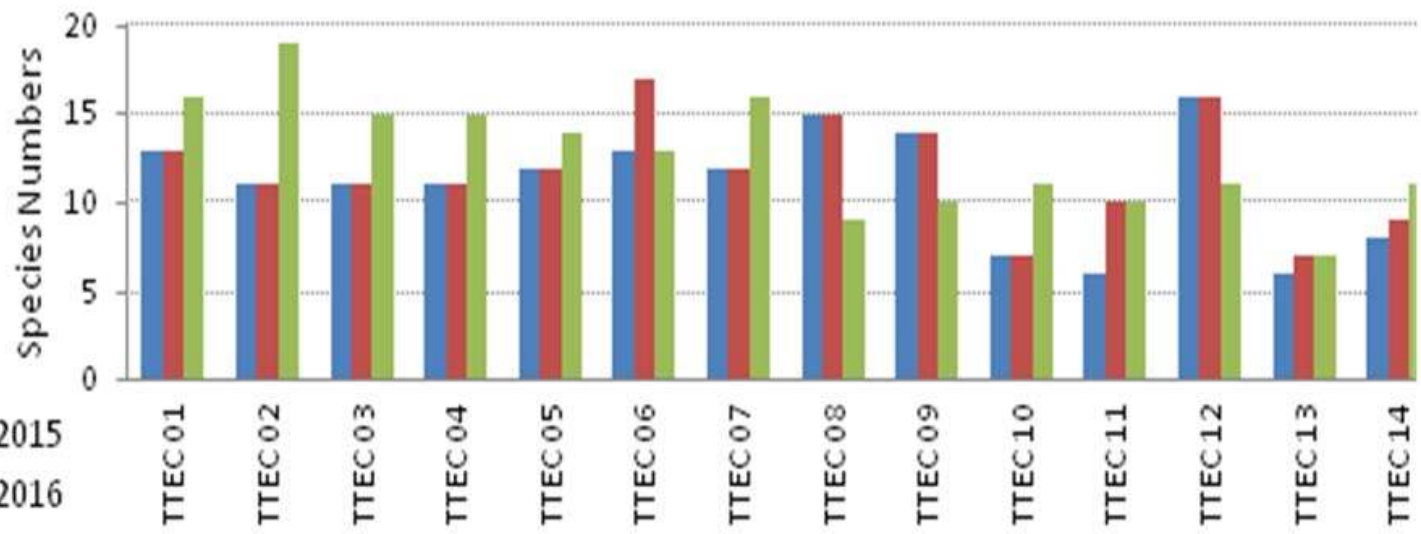

2017

\section{Study Sites}

Gambar 3. Perkembangan jumlah spesies ikan indikator menurut tahun monitoring.

Figure 3. Trend of species numbers for indicator fishes by the yearly monitoring.

Individual number rations of the indicatorfish group identified by years of 2015,2016 and 2017 at the same transect areas

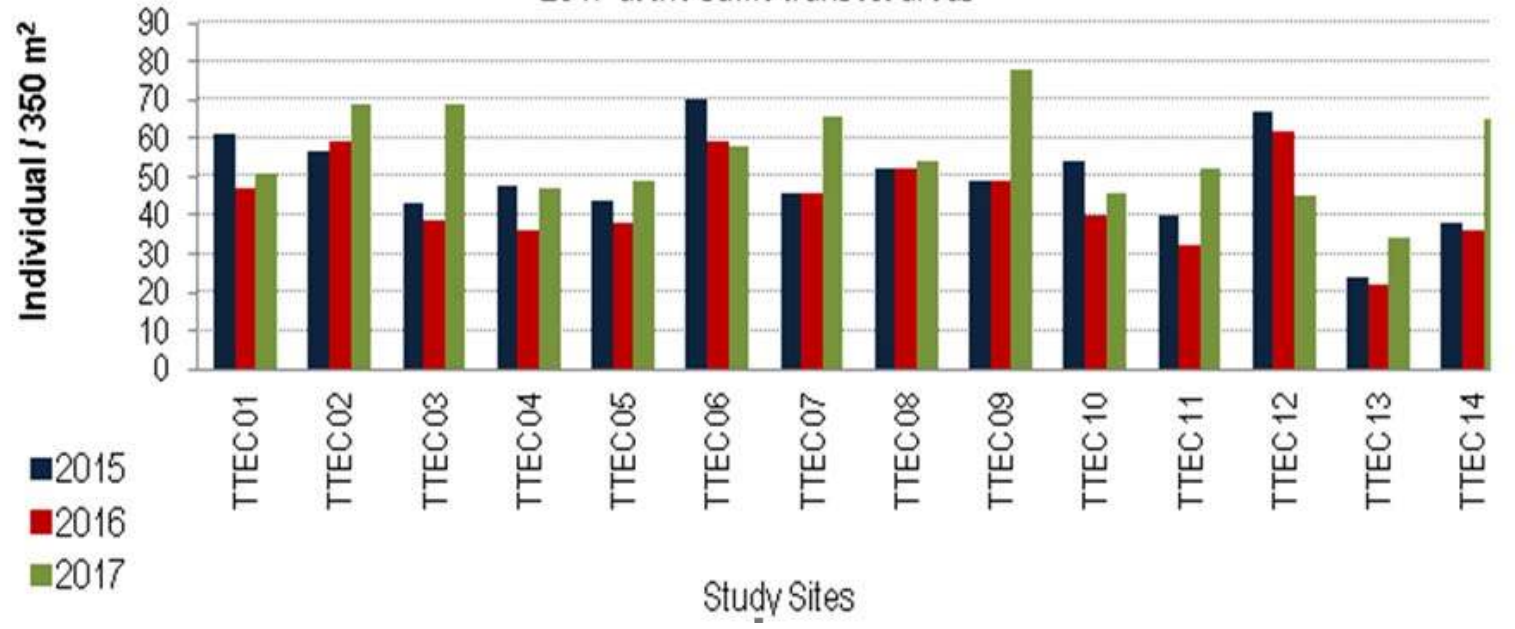

Gambar 4. Perkembangan jumlah individu ikan indikator menurut tahun monitoring.

Figure 4 . Trend of individual numbers for indicator fishes by the yearly monitoring.

Tabel 6. Sepuluh besar dominansi spesies ikan indikator menurut tahun monitoring.

Table 6 . The tenth top of indicator fishes by yearly monitoring.

2015

Chaetodon kleinii

Chaetodon lunulatus

Chaetodon melannotus

Chaetodon rafflesii

Chaetodon triangulum

Chaetodon trifascialis

Chaetodon trifasciatus

Chaetodon vagabundus

Heniochus chrysostomus

Heniochus varius
Year

2016

Chaetodon kleinii

Chaetodon lunulatus

Chaetodon melannotus

Chaetodon rafflesii

Chaetodon triangulum

Chaetodon trifascialis

Chaetodon trifasciatus

Chaetodon vagabundus

Forcipiger flavissimus

Heniochus varius
2017

Chaetodon baronessa

Chaetodon kleinii

Chaetodon lunulatus

Chaetodon melannotus

Chaetodon ocellicaudus

Chaetodon octofasciatus

Chaetodon trifascialis

Chaetodon vagabundus

Heniochus chrysostomus

Heniochus varius 


\section{Perubahan Ikan Karang}

Umumnya jumlah spesies ikan karang dari 7 famili teridentifikasi lebih banyak dari tahun 2015 dibanding tahun 2017. Total spesies pada tahun 2015 sebesar 64 spesies dan kemudian meningkat menjadi 70 pada 2016 serta 77 species pada 2017. Rata-rata jumlah spesies pada 2015 sebesar $18 \pm 3$ spesies, pada 2016 sebesar $20 \pm 4$ spesies dan pada 2017 sebesar $26 \pm 6$ spesies. Secara umum kehadiran ikan karang mengalami peningkatan, hanya pada stasiun TTEC 08,10 dan 12 yang mengalami penurunan tingkat kehadiran spesies (Gambar 5).

Kepadatan ikan terumbu karang per transek, seperti juga sediaannya dalam hektar, meningkat di sepuluh stasiun penelitian (Gambar 6). Rata-rata kepadatan pada 2015 sebesar $146 \pm 46$ ekor/350 atau setara dengan sediaan $4.182 \pm 1.320$ ekor/ha, dan pada 2016 sebesar $167 \pm 56$ atau setara dengan sediaan $4.784 \pm 1.614$ ekor/ha serta pada 2017 sebesar $197 \pm 40$ ekor $/ 350 \mathrm{~m} 2$ atau setara dengan sediaan $5.641 \pm 1.155$ ekor/ha, dimana galat bakunya menurun. Peningkatan kepadatan dan sediaan terjadi pada stasiun TTEC 01, 02, 03, 05, 06, 07, 09, 11, 13, dan 14. Penurunan tingkat kepadatan terjadi pada stasiun TTEC 04, 08, 10, dan 12. Peningkatan yang drastis terjadi pada stasiun TTEC 09 sebagai akibat dari meningkatnya jumlah anakan Ctenochaetus binotatus, Ctenochaetus striatus, dan Scarus gobban. Sebaliknya penuruan jumlah individu yang drastis terjadi pada stasiun TTEC 04 sebagai akibat menurunnya ukuran populasi Lutjanus gibbus.

Kenaikan jumlah individu atau kepadatan tidak diikuti oleh kenaikan biomassa. Pada sebagian terbesar stasiun penelitian terjadi penurunan biomassa (Gambar 7). Rata-rata sediaan pada 2015 sebesar $438 \pm 244 \mathrm{~kg} / \mathrm{ha}$ dan pada 2016 meningkat menjadi $540 \pm 242 \mathrm{~kg} / \mathrm{ha}$, dan kemudian justru menurun menjadi $392 \pm 162 \mathrm{~kg} / \mathrm{ha}$ pada 2017. Penurunan biomassa atau sediaan terjadi pada stasiun TTEC 01, 04, 05, 06, 07, 08, 10, 11, 12, dan 14. Sediaan ikan 2017 yang kembali ke nilai biomassa 2015 adalah ditemukan pada Stasiun TTEC 05, 06, dan 11, sedangkan penurunan drastis terjadi pada stasiun TTEC 08 dan TTEC 10, yaitu sebagai akibat dari ukuran tubuh kelompok ikan herbivora sebagian besar merupakan ukuran anakan. Sebaliknya peningkatan sediaan terjadi pada stasiun TTEC 02, 03, 09, dan 13.

Kenaikan sediaan di empat stasiun tersebut disebabkan oleh ditemukannya beberapa spesies ikan berukuran besar dalam jumlah yang relatif banyak, seperti Scarus spp., Chlorurus spp., Naso spp., Cephalopholis cyanostigma, Plectropomus leopardus, Plectropomus maculatus, Lutjanus biguttatus, Litjanus fulviflamma, Lutjanusb gibbus, Plectorinchus lineata, dan Siganus vermicularis.

Perkembangan komposisi individual antar kelompok herbivora dan karnivora selama tiga tahun memperlihatkan kecenderungan yang sama (Gambar 8). Dalam tiga tahun monitoring, secara umum kelompok ikan herbivora selalu lebih banyak dari yang karnivora. Urutan komposisinya adalah sebagai berikut: famili Acanthuridae, Scaridae dan Lutjanidae masih mendominasi di urutan tiga besar, sedangkan urutan ke empat adalah Siganidae. Hal ini dapat terjadi karena banyaknya anakan ikan dan adanya ikan bergerombol (schooling) dan/atau dalam keempat famili tersebut. Beberapa spesies Acanthuridae dan Scaridae berikut ini adalah populasi ikan yang dijumpai dalam bentuk anakan yang melimpah, yaitu Acanthurus pyroferus, Ctenochaetus binotatus,Ct. striatus, Chlorurus bleekeri, Chl.sordidus, Scarus dimidiatus, S. ghobban, dan Zebrasoma scopas. Beberapa spesies yang terlihat bergerombol adalah Lutjanus biguttatus, L.gibbus, dan Siganus vulpinus.

\section{Kehadiran Ikan Indikator}

Total jumlah spesies kelompok ikan indikator (Chaetodontidae) di perairan Ternate dan sekitarnya masih cukup tinggi di bandingkan dengan lokasi lain, seperti Wakatobi yang hanya dijumpai 28 spesies (Tuti et al. 2016) atau Buton yang dijumpai 25 - 29 spesies (Suharsono 2017). Namun sebaran spesies pada masing-masing stasiun penelitian di Ternate dan sekitarnya tidak mencapai batas tertinggi dari spesies indikator yang dijumpai selama sensus, bahkan pada dua lokasi dijumpai jumlahnya spesiesnya yang terendah, seperti stasiun TTEC 08 dan 13. Dengan memperhatikan nilai rata-rata jumlah spesies atau jumlah individu dan nilai tertinggi serta nilai terendahnya dapat dinyatakan bahwa sebaran spesies dan individual ikan indikator tidak merata untuk setiap stasiun. Hal ini menunjukkan bahwa lokasi terumbu karang memiliki daya dukung yang berbeda untuk kehadiran ikan dari famili Chaetodontidae. Pada lokasi dengan jumlah spesies dan jumlah individu yang terendah dapat dipertimbangkan sebagai lokasi yang kurang baik (Pratchett dan Berumen 2008). 


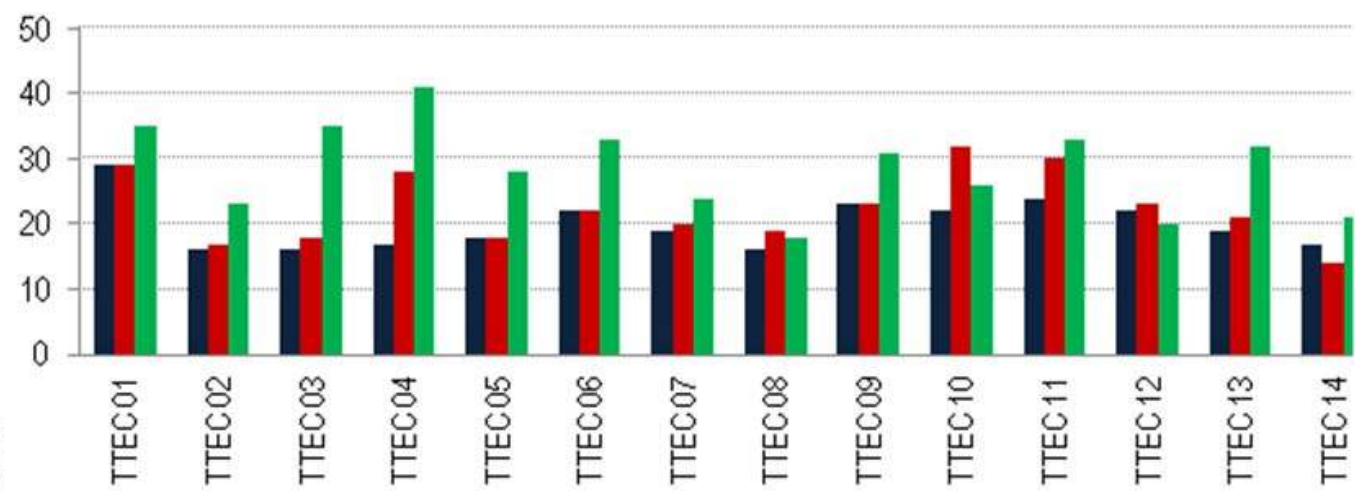

Study Sites

Gambar 5.Perkembangan jumlah spesies ikan terumbu karang menurut tahun monitoring.

Figure 5.Trend of species numbers for coral reef fishes during monitoring years.
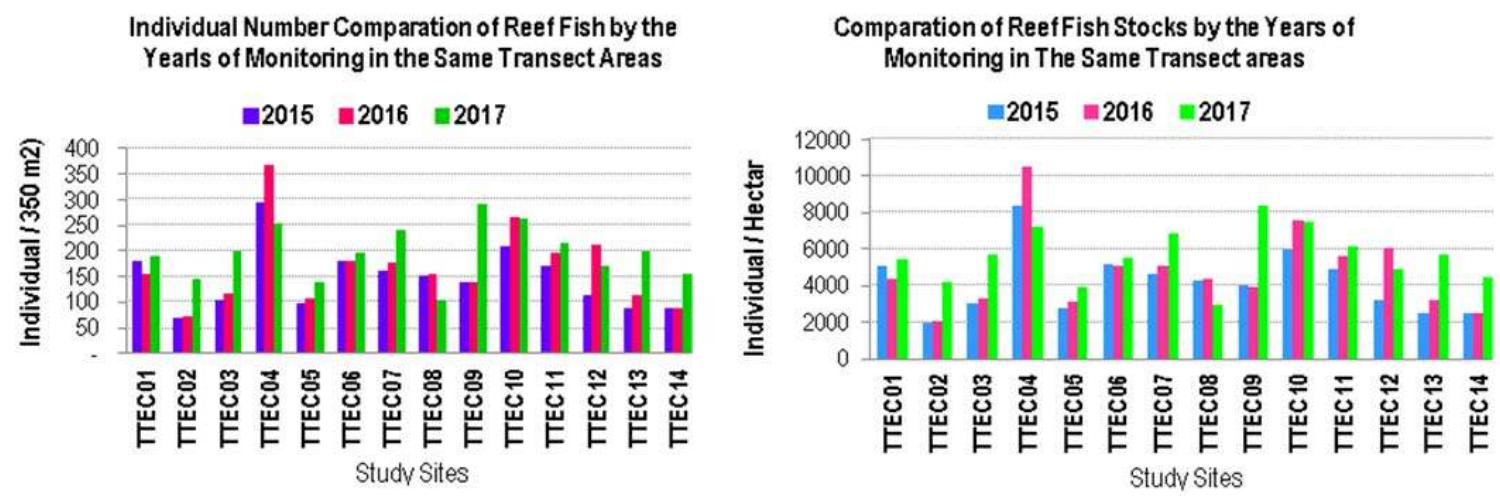

Gambar 6.Perkembangan kepadatan (kiri) dan sediaan (kanan) ikan terumbu karang menurut tahun monitoring. Figure 6. Trend of density (left) and stock (right) for coral reef fishes by the years of monitoring.

\section{Biomass Comparation of Reef Fishes by the Years of Monitoring in the Same Transect Areas}

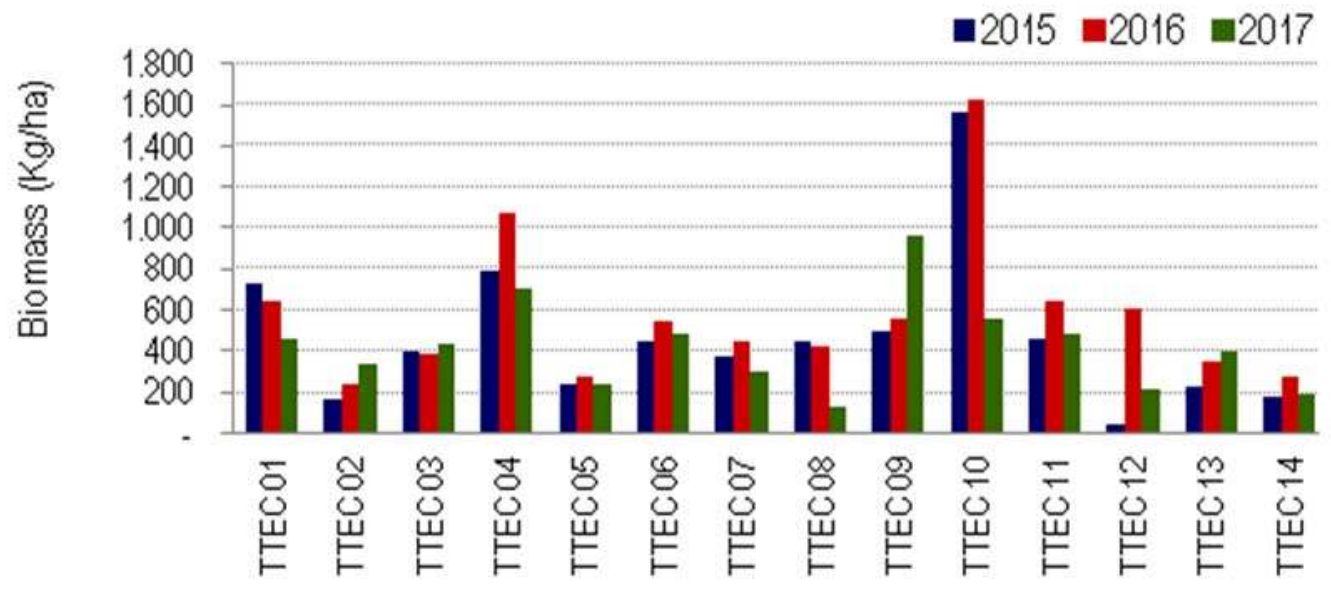

Study Sites

Gambar 7. Perkembangan biomassa per hektar ikan terumbu karang menurut tahun monitoring.

Figure 7. Trend of reef fish biomass per hectar during monitoring years. 


\section{Family Composition by Individual Numbers and the Years of Monitoring}

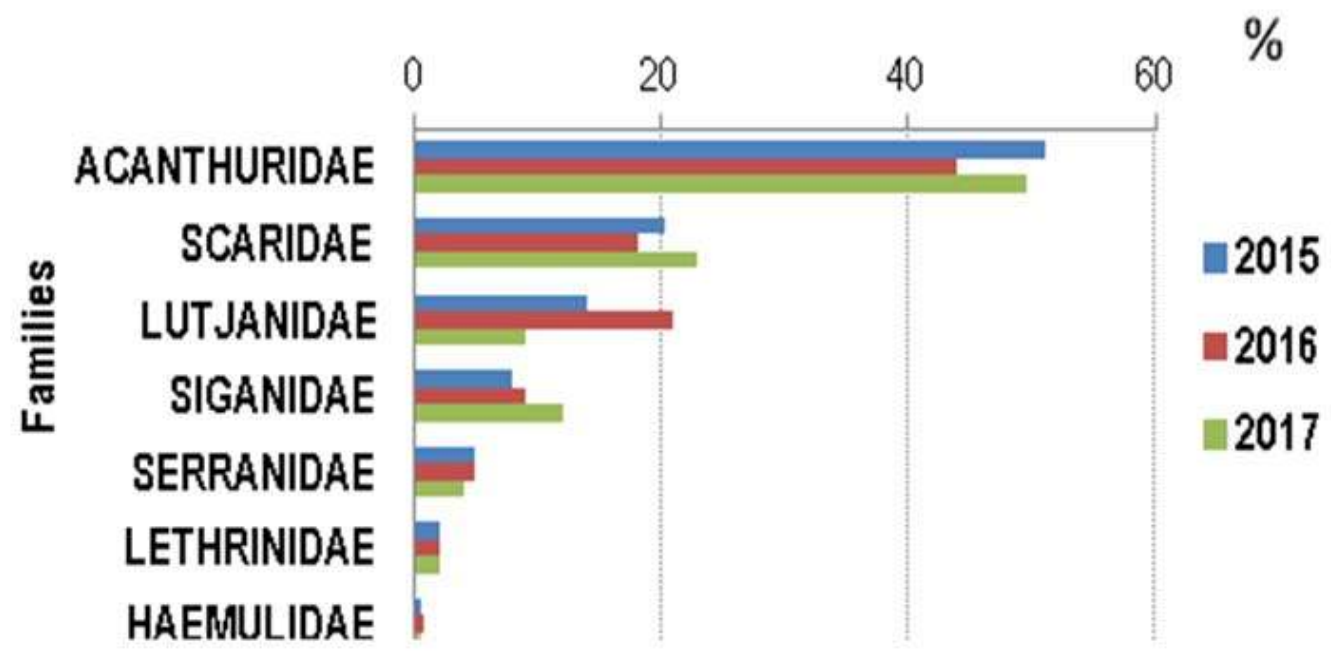

Gambar 8. Perkembangan komposisi famili ikan karang menurut jumlah individual dan tahun monitoring. Figure 8 . Trend of family composition for reef fishes by individual numbers and monitoring years.

\section{Pembahasan}

Menurut Cox et al. (2013) kehadiran dan kelimpahan ikan indikator yang bersifat obligat karang sesuai dengan keberadaan karang dan lifeform karang, sebagaimana juga menurut Coker et al. (2014) ketersediaan makanan (diet) yang sesuai dengan kesukaannya. Keanekaragaman ikan indikator di lokasi penelitian tercatat lebih dari 10 spesies, hal ini menunjukkan bahwa terumbu karang tergolong sehat sedang (Navaro dan Bouchon 1989; Nash 1988). Baik dari segi jumlah spesies maupun jumlah individu dan perkembangannya selama tiga tahun $(2015 \mathrm{~s} / \mathrm{d}$ 2017), lokasi stasiun TTEC 13 (Desa Dodinga, Halmahera Barat) adalah lokasi dengan kondisi perairan karang yang terburuk. Sebaliknya lokasi stasiun TTEC 02 (Ternate Utara) adalah lokasi perairan karang yang tergolong kategori "baik". Selebihnya lokasi-lokasi seperti di stasiun TTEC 01 (Pulau Hirri), TTEC 03 (Ternate Timur), TTEC 06 (Pulau Maitara), TTEC 07 (Pulau Maitara) dan TTEC 09 (Tidore Timur Laut), TTEC 10 (Pulau kecil di sebelah Timur Tidore), TTEC 11 (Tidore Timur), TTEC 12 (Sidangole, Halmahera) dan TTEC 14 (Desa Sofifi, Halmahera) adalah tergolong perairan dengan lingkungan perairan karang dengan kategori "sedang".

Penambahan spesies dan jumlah individu ikan indikator pada 2017 terjadi pada sebagian besar stasiun penelitian dibanding tahun basis 2015. Penambahan spesies tidak besar dan variasinya berkisar pada angka 2 sampai 8 spesies pada 10 stasiun, sedangkan penambahan jumlah individu bervariasi cukup besar, yaitu antara 2 sampai 27 ekor pada 9 stasiun atau pengurangan jumlah individunya antara 1 sampai 22 ekor pada 6 stasiun. Meskipun terdapat variasi penambahan dan/atau pengurangan jumlah species dan individu ikan, perbedaan total spesies ikan indikator yang teridentifikasi pada 2015 dan 2017 hanya 4 spesies dan perbedaan total individual yang tersensus pada kedua tahun tersebut sebesar 90 ekor. Keduanya pada tahun 2017 lebih tinggi dari 2015.

Komposisi ikan Chaetodontidae baik berdasarkan jumlah spesies maupun jumlah individu bergantung pada sifat fungsional dari famili ini yang dikategorikan sebagai coralivora yang bersifat obligat, facultatif atau lebih kearah generalist dalam memilih makanannya (Pratchett et al. 2013). Untuk alasan itu, distribusi ikan ini dalam wilayah terumbu karang dikatakan berkorelasi positif dengan kondisi substrat dan fauna karang itu sendiri yang menyediakan makanan kegemarannya (Krajewski dan Floeter 2011; Komyakova et al. 2013). Dengan demikian variasi komposisi spesies dan jumlah individu ikan kelompok Chaetodontidae memberikan petunjuk baik secara spasial maupun temporal adanya perubahan kondisi terumbu karang sebagai habitatnya ( Graham dan Nash 2012; Coker et al. 2013).

Seperti juga ikan famili Chaetodontidae, famili-famili ikan terumbu karang yang lain juga memiliki co-evolusi dalam perkembangannya bersama terumbu karang, sehingga membentuk 
struktur komunitasnya. Keanekaragaman, komposisi dan pengembangan ukuran populasinya berhubungan dengan kompleksitas terumbu karang (Komyakova et al. 2013). Substrat terumbu karang mendukung beragam fungsi atau peran ikan mulai dari tingkat habitat mikro, dimana ikan memiliki beragam diet atau pola makan, sehingga beragam ikan dapat menetap berdampingan dan mencari makan di terumbu karang yang membentuk variasi dalam keanekaragaman (Wen et al. 2013).

Keragaman spesies dan biomassa ikan, tetapi tidak untuk kelimpahan ikan, biasanya berkorelasi positif dengan kompleksitas bangunan dasar terumbu (Komyakova et al. 2013). di perairan Ternate dan sekitarnya, kenaikan jumlah spesies dan kelimpahan umumnya tidak diikuti oleh kenaikan biomassa. Kenaikan kelimpahan dan biomassa yang berarti selama tiga tahun kegiatan monitoring ditemukan pada stasiun TTEC 09 . Kenaikan keragaman spesies ikan yang menonjol selama tiga tahun ditemukan stasiun TTEC 03, 04, dan 13. Stasiun-stasiun tersebut dapat dipertimbangkan sebagai area yang memiliki kompleksitas substrat terumbu yang baik untuk ikan terumbu karang.

Dari segi komposisi antara herbivora dan karnivora, komposisi kelompok ikan herbivora di perairan Ternate dan sekitarnya di semua stasiun lebih dominan dibanding karnivora (Tabel 5 dan 6) dan komposisi ini tidak berubah selama tiga tahun monitoring dilakukan. Padahal pada situasi terumbu karang yang sehat, karnivora umumnya dijumpai antara 50 sampai $70 \%$ dan kelompok herbivora sekitar 15\% (Nybakken 1992). Dominasi kelompok herbivora ini adalah petunjuk bahwa perkembangan alga terjadi secara lebih besar pada area terumbu karang yang rusak. Dominasi komposisi herbivora yang tertinggi ditemukan pada Stasiun TTEC 09. Seperti diketahui bahwa herbivora berperan penting untuk mengontrol pertumbuhan alga dan berfungsi dalam proses resiliensi karang (Obura dan Grimsditch 2009; Hughes et al. 2007) .

Seperti disebutkan di atas bahwa kenaikan jumlah spesies dan jumlah individu ikan dari 7 famili terpilih pada kebanyakan stasiun di tahun 2017 tidak disertai dengan kenaikan biomassa. Beberapa spesies dari kelompok ikan herbivora yang bersifat soliter ditemukan dengan kelimpahan yang tinggi tetapi dalam ukuran kecil atau stadium anakan dan beberapa karnivora seperti ikan Serranidae yang soliter juga banyak ditemukan masih dalam ukuran kecil, seperti juga ikan kakap baik yang bergerombol maupun soliter ditemukan dalam ukuran kecil dan ukuran anakan. Hal ini menunjukkan bahwa telah terjadi pergantian generasi ikan. Ikan-ikan ukuran kecil lebih dominan, dimana kontrol pengelolaan perikanan untuk target tangkapan ukuran panen lebih intensif dan kemudian kontrol kelompok ikan karnivora atas ikan herbivora berukuran kecil menurun. Seperti diketahui bahwa komposisi famili ikan karnivora jauh lebih rendah dari kelompok ikan herbivora.

Dibandingkan dengan hasil monitoring di Wakatobi 2016 (Tuti et al. 2016), jumlah spesies untuk masing-masing kelompok ikan herbivora dari hasil monitoring di Ternate dan sekitarnya pada 2017 hanya berbeda satu spesies, sedangkan perbandingannya dengan kelompok ikan karnivora cukup jelas, terutama kelompok Serannidae lebih rendah satu spesies, kelompok Lutjanidae lebih rendah empat spesies, kelompok Lethrinidae lebih rendah 4 spesies dan kelompok Haemulidae tidak ada perbedaan. Selain itu, perbedaan jumlah spesies hasil monitoring di Ternate 2017 dengan hasil penelitian di Maluku Tenggara Barat menyebutkan bahwa kelompok ikan herbivora sebanding, tetapi kelompok ikan karnivora lebih rendah, dimana Serranidae lebih tinggi satu spesies, Lutjanidae lebih rendah tujuh spesies, Lethrinidae lebih rendah 4 spesies dan Haemulidae lebih rendah satu spesies (Arief dan Edrus 2017). Hal ini menunjukkan bahwa perairan karang di Ternate dapat mempertahankan komunitas ikan herbivora seperti juga perairan karang di tempat lain, tetapi kehadiran kelompok ikan karnivora terutama ikan target komersil masih rendah. Hampir semua stasiun penelitian di Ternate dan sekitar adalah dekat dengan pemukiman warga pesisir, sehinga dapat diasumsikan bahwa usaha perikanan tangkap berlangsung intensif dan ini berpengaruh pada status biodiversitas ikan terumbu karang.

\section{Kesimpulan}

Komunitas ikan indikator dari kelompok koralivora, seperti juga kelompok herbivora dan karnivora mengalami peningkatan selama tiga tahun dalam jumlah spesies dan jumlah individu atau kepadatan pada sebagian besar stasiun penelitian, sementara sebaran spesiesnya di tiap lokasi stasiun cenderung tidak merata, sehingga pada lokasi penelitian keragaman spesiesnya tidak mencapai jumlah yang maksimal dan perairan desa Dodinga adalah yang terburuk. Pada rentang waktu yang sama, biomassa ikan kelompok herbivora dan karnivora tidak mengalami kenaikan pada sebagian besar lokasi penelitian, kecuali kenaikan terbatas hanya pada perairan Timur Tidore di stasiun TTEC 09 saja. Dari segi komposisi, dominasi kelompok ikan herbivora atas karnivora selalu terjadi setiap 
tahun monitoring dan urutan dominasi famili dari yang tertinggi sampai yang terendah adalah sama setiap tahun, yaitu Acanthuridae, Scaridae, Lutjanidae, Siganidae, Serranidae, Lethrinidae, dan Haemulidae.

\section{Persantunan}

Kegiatan monitoring ini adalah bagian dari kegiatan RHM COREMAP CTI T.A 2015 s/d 2017. Terima kasih diucapkan kepada semua pihak yang telah membantu kelancaran kegiatan ini dan juga atas dukungan Stasiun Pengamatan Laut Ternate serta bapak Femy D. Hukom dan Tim Ikan RHM 2015 dan 2016.

\section{Daftar Pustaka}

Allen, G. R., and M. V. Erdmann. 2012. Reef fishes of the east indies. Tropical Reef Research, Perth.

Allen, G. R, P. Humann, R. Steene, and N. Deloach. 2009. Reef fish identification: tropical pacific. New World Publication, El Cajon CANew World Publications.

Allen, Gerald R., and M. Adrim. 2003. Review: article coral reef fishes of indonesia. Zoological Studies 42 (1): 1-72.

Arief, Syahrul, and I. N. Edrus. 2017. Struktur komunitas ikan karang di perairan kabupaten maluku barat daya. Jurnal Penelitian Perikanan Indonesia 16 (3): 235-50.

Coker, D. J., S. K. Wilson, and M. S. Pratchett. 2014. Importance of live coral habitat for reef fishes. Reviews in Fish Biology and Fisheries 24 (1): 89-126.

Cox, E., M. L. Berumen, B. G. Kapoor. 2013. Corallivory. In Biology of Butterflyfishes, CRC Press.

Dartnall, H.J. and Jones, M. 1986. A manual of survey methods of living resources in coastal area: Asean Australia cooperative programme marine science handbook. AIMS Townsville

Froese, R., and D. Pauly. 2018. Fish base. www.fishbase.org. 24 Desember 2018

Giyanto, Manuputty Anna EW, Abrar Muhammad, Siringoringo Rikoh M, Suharti Sasanti R, Wibowo Kunto, Edrus Isa Nagib dan Ucu Y. Arbi. 2014. Panduan Monitoring Kesehatan Terumbu Karang. Pusat Penelitian Oseanografi LIPI. Jakarta. $63 \mathrm{hlm}$

Graham, N. A. J., and K. L. Nash. 2012. The importance of structural complexity in coral reef ecosystems. Coral Reefs 32 (2): 315-26.

Graham, N. A. J., P. Chabanet, R. D. Evans, S. Jennings, Y. Letourneur, M. A. MacNeil, T.
R. McClanahan, M. C. Öhman, N. V. C. Polunin, and S. K. Wilson. 2011. Extinction vulnerability of coral reef fishes. Ecology Letters 14 (4), John Wiley \& Sons.

Hoegh-Guldberg, O., Z. Dubinsky and N. Stambler, editors. 2011. The impact of climate change on coral reef ecosystems. In Coral Reefs: An Ecosystem in Transition, Dordrecht, Springer Netherlands.

Hughes, T. P., M. J. Rodrigues, D. R. Bellwood, D. Ceccarelli, O. Hoegh-guldberg, L. Mccook, N. Moltschaniwskyj, M. S. Pratchett, R. S. Steneck, and B. Willis. 2007. Report phase shifts, herbivory, and the resilience of coral reefs to climate change. Current Biology 17: $360-65$.

Komyakova, V., P. L. Munday, and G. P. Jones. 2013. Relative importance of coral cover, habitat complexity and diversity in determining the structure of reef fish communities. PLoS ONE 8 (12): 1-12.

Krajewski, J. P., and S. R. Floeter. 2011. Reef fish community structure of the fernando de noronha archipelago (equatorial western atlantic): the influence of exposure and benthic composition. Environmental Biology of Fishes 92 (1): 25-40.

Makatipu, P. C, F. M. Hukom, Giyanto, J. Sohuoka, A. Budiyanto, M. H. Azkab, U. Y. Arbi, I. W. E. Dharmawan, B. Hermanto, D. Nurdiansah, S. I. Patty, N. Akbar, dan M. Djabbar. 2015. Survei baseline coremap cti kondisi terumbu karang dan ekosistem terkait di Ternate, Tidore dan sekitarnya, Maluku Utara. Laporan. COREMAP-CTI, P2O-LIPI, Jakarta.

Michael, A.W. 2011. Cyanide and dynamite fishing, who's really responsible?. Available: www.ocean_environment.com.au (July 2018)

Obura, D., and G. Grimsditch. 2009. Resilience Assessment of Coral Reefs Bleaching and Thermal Stress. IUCN. 70 pp.

Pratchett, M. S., N. A. J. Graham, and A. J. Cole. 2013. Specialist corallivores dominate butterflyfish assemblages in coral-dominated reef habitats. Journal of Fish Biology 82 (4): 1177-1191.

Reese, E. S. 1977. Coevolution of corals and coral feeding fishes of the Family Chaetodontidae. Proceedings of the 3rd International Coral Reef Symposium 1: 267-274

Shidqi, R. A., B. Pamuji, T. Sulistiantoro, M. Risza, A. N. Faozi, A. N. Muhammad, M. R. Muharam, E.D. Putri, R. Hartini, B. Valentina, R.Z. Fakhri, G.G. Putra, R. Kurniawan, A. Pratomo and A.D. Syakti. 2018. Coral health monitoring at Melinjo island and Saktu island: 
influence from Jakarta bay. Regional Studies in Marine Science 18: 237-242.

Slade, L. M., and B. Kalangahe. 2015. Dynamite fishing in Tanzania. Marine Pollution Bulletin 101 (2): 491-96.

Suharsono. 2017. Monitoring kesehatan terumbu karang dan ekosistem terkait di Kabupaten Buton dan sekitarnya, Sulawesi Tenggara. Bunga Rampai Laporan. COREMAP-CTI, P2O-LIPI, Jakarta, in printing.

Suyarso, M. Y. Iswari, A. E. W. Manuputty, J. Sohuka, P. Makatipu, F. D. Hukom, H. A. W. Cappenberg, I. Happy, N. Akbar, A. Budiyanto, S. Patty, A. S. Leatemia, J. Picasouw, dan I. W. E. Dharmawan. 2016. Monitoring kesehatan terumbu karang dan ekosistem terkait perairan Ternate dan sekitarnya Propinsi Maluku Utara. Laporan. COREMAP-CTI, P2O-LIPI, Jakarta.
Tuti, Y., Suyarso, S. R. Suharti, H. A. W. Cappenberg, I. N. Edrus, I. W. E. Dharmawan, T. Aryono, R. S. Utama, A. Budiyanto, A. Salatalohi, dan S. Sulha. 2016. Monitoring kesehatan terumbu karang dan ekosistem terkait di Kabupaten Wakatobi, Sulawesi Tenggara. Laporan. COREMAP-CTI, P2OLIPI, Jakarta.

Wen, C. K. C., M. S. Pratchett, G. R. Almany, and G. P. Jones. 2013. Patterns of recruitment and microhabitat associations for three predatory coral reef fishes on the southern great barrier reef, Australia. Coral Reefs 32 (2): 389-98.

Wilson J. R. dan A. L. Green. 2009. Metode pemantauan biologi untuk menilai kesehatan terumbu karang dan efektivitas pengelolaan kawasan konservasi laut di indonesia (Terjemahan). 